\title{
Water operator partnerships as a model to achieve the Millenium Development Goals for water supply? Lessons from four cities in Mozambique
}

\author{
Gabriel Patrón Coppel and Klaas Schwartz \\ Department of Management and Institutions, UNESCO-IHE Institute for Water Education, PO Box 3015, \\ 2601 DA Delft, The Netherlands
}

\begin{abstract}
In the void left by the declining popularity of public-private partnerships, the concept of 'water operator partnerships' (WOPs) has increasingly been promoted as an alternative for improving water services provision in developing countries. This paper assesses the potential of such partnerships as a 'model' for contributing to the MDGs, by focusing on 4 water utilities in Mozambique. Although, the study found these partnerships to be successful, it is more sceptical about the potential for this type of water operator partnership to significantly contribute towards achieving the MDGs. The main reason for this is that the replicability of the partnership-model studied in Mozambique was found to be quite limited. The case presented in this article highlights 3 main lessons for water operator partnerships in the water services sector. First, the availability of investment funds is a crucial component of a partnership. Without access to such funds the impact of such a partnership is likely to be limited. Secondly, the level of commitment to the partnership needs to be high if it is to be successful. This commitment is likely to take shape in the form of both financial commitment as well as commitment of time and effort of the organisations involved. Thirdly, even if the partnership is a success, the question of how sustainable the achieved performance gains are remains a point of concern. All in all, although we acknowledge the success achieved by the studied partnership, the findings have made us hesitant about the potential for replicating this 'model' at a large scale.
\end{abstract}

Keywords: partnerships, Millennium Development Goals, water supply, Mozambique

\section{Introduction}

The water services sector in most developing countries has long suffered from poor performance of its public water utilities. Apart from problems of service coverage of between 50\% and $80 \%$ (WHO/UNICEF, 2008), other problems that plague water utilities include high unaccounted-for-water, which often averages between $40 \%$ and $60 \%$, and overstaffing (Mwanza, 2005). Moreover, the service providers are often confronted with financial problems due to a combination of low tariffs, poor consumer records and inefficient billing and collection practices (World Bank, 1994; Foster, 1996; Mwanza, 2004). The poor performance of water utilities has led to a situation in which 1.2 billion people lack access to adequate water supply services and 2.4 billion people lack access to adequate sanitation services (WHO/UNICEF, 2006).

The Millenium Development Goal (MDG) targets for water supply services state that the population without access to adequate water services should be halved by 2015 . Although progress has been reported on these targets, access to adequate water services in Sub-Saharan Africa, in particular, appears to be lacking. Between 1990 and 2006 the percentage of people with access to adequate water services increased from $49 \%$ to $58 \%$; this represents an increase of only $9 \%$ in 16 years $(\mathrm{WHO} /$ UNICEF, 2008). The challenges of achieving the MDG target for water supply are multidimensional in nature. Firstly, the

\footnotetext{
* To whom all correspondence should be addressed.

푤 +31-15-2151715; fax: +31-15-2122921; e-mail: k.schwartz@unesco-ihe.org

Received 17 August 2010; accepted in revised form 5 September 2011.
}

MDGs are argued to require innovative (local) financial tools to finance increased coverage (Brown and Holcombe, 2004; Metha et al., 2005). Secondly, a strong institutional framework is believed to be a prerequisite for achieving the MDG targets on water and sanitation. Sound sector policies are required to lead the drive to achievement of the targets, and a strong institutional framework would also provide better access to (international) investment capital (Bourguinon et al., 2008). Linked to the strong institutional framework is organisational capacity, which is also frequently mentioned as a determining factor in the ability to achieve the MDGs. This capacity concerns both sector organisations (Ministries, national water agencies, etc.) as well as water utilities (Metha et al., 2005). Finally, 'appropriate' technologies are put forward as a means of achieving the MDG targets (Brown and Holcombe, 2004; Mara et al., 2007; Mara and Alabaster, 2008).

\section{The rise of partnerships}

Over the past few decades, the provision of (public) services through 'partnerships' has increasingly gained importance, both in developed as well as developing countries (Klijn and Koppenjan, 2000; Teisman and Klijn, 2002; OECD, 2006). In the past 2 decades partnerships 'have become important instruments for addressing problems of global development and reaching the Millenium Development Goals' (Kolk et al., 2008: 263). Although in this paper the term 'partnerships' is used, other terms may be used to describe a similar arrangement such as 'social alliances' (Kolk et al., 2008) or 'networks' (Provan and Brinton Milward, 2001). These partnerships, which in reality encompass a wide range of arrangements involving different partners, are increasingly presented as an alternative to service 
provision by government agencies, fully privatised service delivery and community-based service provision. The idea is that these partnerships (involving government, the private sector and possibly the community) will be better able to meet the complex challenges that many countries face in providing (public) services.

\section{Public-private partnerships in the water sector}

In the water supply and sanitation sector the term 'partnership' entered into the mainstream in the 1980s and 1990s, when a coalition of international development banks, bilateral donors and water sector professionals strongly advocated an increasing role for the private sector in the provision of water services (Idelovitch and Ringskog, 1995; Nickson, 1997; Panayatou, 1997; World Bank. 1997; Spiller and Davidoff. 1999). Private sector involvement was believed to lead to efficiency gains, remove politics from the sector and be a source of investment capital (Brown, 2002). Initial optimism for the beneficial impact of private sector involvement was enormous, even if the actual implementation remained controversial (Hall and Lobina, 2000). The term used to highlight private sector involvement was public-private partnership. This terminology highlights 2 things. First, it stresses that private sector involvement does not exclude the public sector and consumers from involvement in the water services sector. Even if private sector involvement is increased, roles and responsibilities of public and community organisations remain. Secondly, the term represents a more acceptable term than the rather blunt-sounding 'privatisation' (Franceys, 2008)

In recent years, however, the gospel of private sector involvement in the water supply and sanitation sector has faded. High-profile concession contracts which once were presented as representing the future of the water services sector collapsed or are facing increasing operational difficulties. Bestknown among the collapsed concession contracts is the concession contract in Cochabamba in Bolivia, which was terminated in 2000 following a period of civil protest often referred to as the 'Water War'. Other well-known concession contracts that were terminated include the El Alto-La Paz concession (2005) in Bolivia and the Buenos Aires concession (2005) in Argentina. Other contracts, such as the concession contracts in Manila and Jakarta, have faced serious operational challenges in the past decade (Jensen, 2005; Braadbaart, 2007). In recent years, it has become apparent that private sector involvement, as it was envisioned and implemented in the 1990s, was not the 'golden solution' that many had believed it to be a decade earlier (Parker and Kirkpatrick, 2005; Prasad, 2006). Illustrative of the declining popularity is the 2003-2004 Action Plan of SUEZ, one of the world's largest private water operators, in which the company highlights that it will 'concentrate on the soundest markets providing the most recurrent revenues starting with the Franco-Belgium domestic market and including the European Union and North America'. The Action Plan continues by explaining that 'exposure to emerging countries, as measured by capital employed, is expected to be reduced by close to one third' (SUEZ, 2003).

\section{Water operator partnerships as a promising alternative?}

In the void left by the declining popularity of public-private partnerships, the concept of 'water operator partnerships' (WOPs) surfaced as a possible alternative for improving service provision in developing countries. In March 2006, the United Nations Secretary-General Advisory Board in Water and
Sanitation (UNSGAB) led by the ex-prime minister of Japan, Ryutaro Hashimoto, developed a Compendium of Actions entitled the Hashimoto Action Plan (Hashimoto, 2006), under the direct request of the Secretary-General, Kofi Annan. The objective of this Plan was to put forward a series of actions aimed at boosting the efforts around the world for achieving the MDG targets on water and sanitation, and WOPs were recommended as a useful mechanism to do so.

Although the concept of WOPs has since been heavily promoted by organisations such as the International Water Association and UN-HABITAT, there still appears to be no generally agreed upon definition for what, exactly, encompasses a WOP. The International Water Association (IWA) defines WOPs as 'any formal or informal collaboration or structured partnership aimed at capacity building on a not-for-profit basis. Partnerships can take a multitude of different forms and have various technical, legal and social shapes on individual circumstances' (IWA et al., 2009). Despite this rather vague and broad definition, the WOPs approach does signal a substantial break from the public-private partnership approach. A fundamental element of the public-private partnership approach was essentially the replacement of a public organisation or utility by a private organisation. The idea was then that the private organisation would be able to operate more effectively and efficiently than the public organisation had. In the WOPs approach, however, emphasis is on capacitating (rather than replacing) the public organisation. The WOPs approach emphasises peer-topeer support and solidarity between service providers.

\section{Research objectives and methodology}

Despite the strong advocacy for WOPs in recent years, very little empirical research has been undertaken into the functioning of such not-for-profit partnerships. Little is known about how these partnerships function, what makes them successful (or not) and to what extent such partnerships will be able to contribute towards achieving the MDGs. In this paper, we aim to (partially) address this gap by focusing on a partnership involving Vitens Evides International of The Netherlands and the Water Supply Investment and Asset Holding Fund (FIPAG) of Mozambique. FIPAG is a public asset holding company temporarily in charge of operating 19 water systems in Mozambique. Vitens Evides International is an international subsidiary of 2 Dutch water supply companies, Vitens and Evides, and undertakes water supply projects in developing countries on a noncommercial basis. In 2004 these 2 organisations entered into a partnership aimed at improving service provision in Chókwe, Inhambane, Maxixe and Xai-Xai in Southern Mozambique. The cities are located within a radius of $128 \mathrm{~km}$ from each other, $360 \mathrm{~km}$ north of the capital Maputo, in the southern part of the country and close to the coast (Inhambane and Maxixe are on the coast).

The reason for selecting this partnership for research is 3 -fold. First of all, the partnership involved considerable (financial) commitment from the different actors. As such, the research focused on a relatively robust form of water operator partnership. Secondly, the fact that the partnership began in 2004 allows for a better analysis of the functioning and impacts of the partnership over time. Thirdly, the level of access to water services in Mozambique is one of the lowest in the world, making it a suitable case study for assessing the potential of such partnerships in achieving the MDGs.

Apart from collecting secondary data by reviewing the available reports and documents, primary data collection 


\begin{tabular}{|l|l|l|}
\hline \multicolumn{2}{|c|}{$\begin{array}{c}\text { Table 1 } \\
\text { List of interviewees }\end{array}$} \\
\hline & Position/Job description & Organisation \\
\hline 1 & 4 Cities Project Assistant & CRA \\
\hline 2 & Financial Expert & Vitens Evides International \\
\hline 3 & Electrical Technician/Chief of Production Department & FIPAG \\
\hline 4 & Analysis and Monitoring Technician/Chief of Consumption Analysis & FIPAG \\
\hline 5 & Commercial Specialist, Technical Assistance Team & FIPAG/Vitens Evides International \\
\hline 6 & Director, FIPAG & FIPAG \\
\hline 7 & Chief of Distribution Department & FIPAG \\
\hline 8 & Director, Vitens Evides International & Vitens Evides International \\
\hline 9 & Commercial Division & FIPAG \\
\hline 10 & Human Resources Specialist, Technical Assistance Team & FIPAG/Vitens Evides International \\
\hline 11 & Investment Coordinator of 4 Cities & FIPAG \\
\hline 12 & Financial Specialist, Technical Assistance Team & FIPAG/Vitens Evides International \\
\hline 13 & Commercial Financial Monitoring Officer & CRA \\
\hline 14 & Resident Manager (1) & Vitens Evides International \\
\hline 15 & Water Expert & Royal Netherlands Embassy \\
\hline 16 & Investment Manager/Coordinator of 4 Cities & FIPAG \\
\hline 17 & Financial Expert & Vitens Evides International \\
\hline 18 & Resident Manager (2) & Vitens Evides International \\
\hline 19 & Water and Sanitation Operations Specialist & World Bank \\
\hline 20 & GIS Specialist, Technical Assistance Team & FIPAG/Vitens Evides International \\
\hline
\end{tabular}

Note: Job titles represent the position during the 2004-2008 period and may have changed since

involved fieldwork in Southern Mozambique between July and November 2009. In this period semi-structured interviews were held with representatives of Vitens Evides International, FIPAG staff in the 4 utilities, FIPAG staff at the Head Office in Maputo, representatives of the Water Supply Regulatory Council (CRA), a representative of the Dutch Embassy and a representative of the World Bank. A list of interviewees is presented in Table 1below.

In the next 2 sections, we introduce the water services sector in Mozambique and provide a brief overview of the partnership between Vitens Evides International and FIPAG. Then, a number of salient features regarding this particular partnership are elaborated upon. In the conclusion, we attempt to draw broader lessons from the presented case.

\section{Water services in Mozambique}

As mentioned, Mozambique has coverage levels for water and sanitation which are among the lowest in the world. Access to safe water officially reached an average of $39.8 \%$ in 2004 (RNE, 2004). According to UNICEF (2003), Mozambique has one of the highest child mortality rates in the world (246 out of every 1000 live births), and 13\% of these deaths are directly attributed to lack of access to clean water and to poor sanitation.

In order to mitigate this situation the Government enacted the Water Law (Law 16/91) in 1991, which provides the general legal framework for the management, protection, conservation, use, control and monitoring of the water resources (Wolters and Van den Horn, 2008). This law was later followed in 1995 by the enactment of the National Water Policy (Resolution 7/95). The main feature of this policy was the establishment of the principle of privatisation of urban water supply services in an attempt to attract private sector participation (CRA, 2009). The policy calls for financially self-sufficient and decentralised autonomous agencies to operate the provision of water supply services, and for these agencies to have management capable of attracting local financial resources to strengthen their physical and human assets (Wolters and Van den Horn, 2008). In summary, the policy aims to achieve decentralisation, to have user involvement and the participation of the private sector, with the Government acting as the regulator, coordinator and facilitator. In 1997 the Government, with the help of the World Bank, created the National Program of Water Development I (PNDA I) aimed at restructuring the urban water sector through sector reforms, institutional capacity building, and policy development, all in preparation for private sector participation. A year later the Water Tariff Policy was introduced (Resolution 60/98), which declared water as an economic good and stated that tariffs should be socially equitable and economically efficient to allow for cost-recovery (AfDB, 2002, CRA, 2009).

In the same year (1998), the Delegated Management Framework (DMF) was created (Decree 72/98), which formed the legal basis for delegating the management and operation of public water supply services though the establishment of management, lease or concession contracts with private companies (Matsinhe et al., 2008). The DMF separated asset management from operations of selected urban systems, and entrusted asset management to a newly-created entity (FIPAG), with the idea that operations would be contracted out to private companies. As part of the DMF the Water Supply Regulatory Council (CRA) was also created. CRA started functioning in 2000; its responsibilities include the regulation of water services and tariffs, protection of consumers and mediation and arbitration between the contracting entity and the operator.

\section{The Vitens Evides International-FIPAG partnership}

After the Dutch water company was created following a merger in 2000 , Vitens decided to allocate a budget of $€ 1$ million per year $(0.3 \%$ of their annual turnover) for international 
development support. After a slight delay, caused by the implementation of the merger, Vitens Evides International (VEI) started its international activities in 2003. In developing a strategy for their international activities, it was decided that the organisation should focus on urban water supply on a non-commercial basis, because that is where specific strengths of the organisation's mother company (Vitens) lay. The non-commercial basis on which VEI operates means that its activities are not geared towards making profits (which would then accrue to the water companies Vitens and Evides). At the same time, VEI does seek to recover the costs above the $€ 1$ million per year which it receives from its parent companies. This means that VEI actively seeks funding opportunities from donors, and tenders to develop their projects.

Because water supply is very capital intensive and $€ 1$ million a year is not nearly enough to construct infrastructure for urban utilities, it was decided to concentrate on management and improvement of water companies. Apart from the technical focus of the organisation, Vitens Evides International also opted for a geographical focus on Africa. Furthermore, with the intention of avoiding discussions about legitimacy of regimes, they decided to opt for countries receiving Dutch development aid.

Vitens' involvement in the Mozambican water sector dates back to June 2003, when they approached FIPAG through the Royal Netherlands Embassy (RNE) in Maputo. The idea was to help the utilities in the cities of Xai-Xai, Chókwe, Maxixe and Inhambane prepare for a large investment project of the African Development Bank (AfDB). The RNE, which was one of the most active donor entities in the water sector in Mozambique, was afraid that the utilities might not be up to the task of managing the new investments. Consequently FIPAG and Vitens signed a Letter of Intent in July of 2003 which outlined the underlying principles of their cooperation.

\section{Technical assistance contract under a management contract framework}

Following the signing of the letter of intent, Vitens Evides International started working with FIPAG in the 4 southern cities. Vitens Evides International offered to do training for the 4 cities and sent a group of experts to assess the situation and draw out a business plan that would describe the nature of the support, the tasks, and the responsibilities. The proposed plan incorporated the idea to mimic a Management Contract as a way to set up targets (performance indicators) for the partnership. The only difference was that the contract would not be legally binding because Vitens Evides International would bear all costs of the partnership. However, it was felt that this 'contract' would nevertheless help to formalise the project and give it some kind of structure. The agreement was that Vitens Evides International would detach 2 permanent staff (one for technical support and the other for resources, billing and collection and customer support). These 2 permanent staff would then be supported by short-term staff, who would attend 2 or 3 times per year for 1 month. The cost for Vitens would be about $€ 350000$ per year, and, since they had $€ 1$ million at their disposal, they were able to use considerable funds for purchasing required materials such as spare parts, pumps, etc. The agreement was finally called a Technical Assistance Contract (TAC) and became effective on 1 January 2005 (RNE, 2004).
The end date of the contract was 31 December 2007, but was later extended to 1 July 2008.

\section{'Call for ideas' and the establishment of a 'public- private partnership'}

In late 2003 the Dutch Ministry for Development Cooperation (DGIS) launched a 'call for ideas' for the creation of publicprivate partnerships between Dutch and foreign companies, as a way to achieve the Netherland's commitment to the MDGs. The chosen partnerships would be granted access to funds from the Dutch Government (through the local Dutch Embassies) in order to implement their ideas. The 'call for ideas' initiative fitted well with Vitens Evides International's ongoing activities in Mozambique. The TAC agreement Vitens Evides International had entered into with FIPAG mimicked a management contract and, as such, linking the TAC to a 'public-private partnership' seemed to be a good opportunity for both parties. A proposal was submitted and eventually selected. DGIS and Vitens Evides International decided that the agreement would be for 3 years (1 July 2005 to 30 June 2008) and that both parties would contribute $€ 1$ million each to the partnership.

On 1 July 2005 the 'PPP' between Vitens Evides International, the RNE (on behalf of DGIS) and FIPAG became effective. In legal terms the PPP entailed a Memorandum of Understanding between the 3 parties and a Grant Agreement between the RNE and Vitens. The objective of the PPP was to create sustainable autonomous water companies that would provide safe water services (RNE, 2004). FIPAG's role was to provide the appropriate framework for the establishment of the autonomous utilities, whilst Vitens Evides International was to provide 'skills and competencies of its staff in utility management towards building capacity' for the utilities in the 4 cities (RNE, 2004). This PPP had a very strong focus on achieving autonomy since this was regarded by the participants (Vitens Evides International and FIPAG) as being the best way in which the water utilities could gain a sustainable level of adequate performance. However, even though autonomy was continuously mentioned as the main purpose, capacity development was implicitly considered to be the key component of the partnership, as highlighted in the TAC.

Vitens provided human resources for capacity building and contributed $€ 1.4$ million that were used to cover human resources costs, some goods and services, and audit costs. DGIS in turn contributed $€ 1$ million through the RNE in Maputo to help cover the costs of the transition period towards autonomy. The contribution of the RNE was not used for compensating Vitens Evides International for their costs. FIPAG also had a contribution to the partnership, of $€ 255,000$, which was to be used for training and goods and services.

\begin{tabular}{|l|r|r|r|r|}
\hline \multicolumn{5}{|c|}{ Table 2 } \\
Overview of the financial contributions to the PPP (in $€$ ) \\
\hline & FIPAG & $\begin{array}{r}\text { Vitens } \\
\text { Evides } \\
\text { International }\end{array}$ & DGIS & TOTAL \\
\hline Human resources costs & & 1305182 & & 1305182 \\
\hline Goods and services & 60000 & 35000 & 625000 & 720000 \\
\hline Operational costs & & & 340000 & 340000 \\
\hline Training courses & 195350 & & 75000 & 270350 \\
\hline Audit costs & & 67500 & & 67500 \\
\hline Contingencies & & & & 0 \\
\hline TOTAL & 255350 & 1407682 & 1040000 & 2703032 \\
\hline
\end{tabular}

Source: RNE (2004) 
Therefore, on July 1, 2005 Vitens Evides International and FIPAG had essentially entered into 2 separate agreements (the TAC and the Memorandum of Understanding which formed the basis of the PPP). It should be emphasised that for Vitens Evides International and FIPAG the main document underlying the partnership was the TAC. The 'PPP' was viewed much more as an opportune way of accessing additional funds to strengthen the technical assistance outlined in the TAC. Vitens Evides International acknowledge that they have used different names when referring to their partnership with FIPAG. They justify this by emphasising that to them it does not matter what name is used as long as they can develop such a partnership and access funds in order to contribute to the development of weaker utilities. However, they do point out the fact that, although Vitens Evides International is a limited liability company, the mother companies (Vitens and Evides) are publicly owned and that Vitens Evides International's support is always on a non-profit basis with social corporate responsibility as their main driver. 'Therefore we prefer to be seen as a public partner instead of private partner and continue working under the so-called "water operator partnership", (Van den Horn, 2009).

\section{Activities undertaken as part of the partnership}

The activities undertaken by the partners as part of the partnership can be subdivided into 4 different categories. These are the training of staff, development of plans, programmes and standard operating procedures, provision of basic materials and the planning of investments coming from the loan from African Development Bank. The various activities are described in greater detail below.

The core task of Vitens Evides International was that of capacity building to improve skills, knowledge, and attitudes of staff of the 4 water utilities. The training of staff was undertaken by having staff of the companies Vitens and Evides visit the 4 utilities. More than 55 of such short missions, with a duration of 3 to 4 weeks each, were undertaken. The short-term staff members were assisted in their capacity-building activities by a group of Mozambican young professionals, which formed the Technical Assistance Team (TAT). This team was formed by approximately 7 people, with specialties in commercial, financial, human resources and technical areas. The TAT was hired directly by Vitens Evides International and received direct training from its staff. Their role was to support VEI's staff on their training and monitoring activities and this was the format used during the entire contract.

Apart from the on-the-job training, VEI organised and paid for several formal training sessions and workshops, either instructed by them or by other institutions, and also organised trips in which the staff of FIPAG visited their mother company in The Netherlands as well as several other water utilities around the world (South Africa, Tanzania, The Philippines, Vietnam, etc.). The training provided was targeted at lower positions in the utilities but also at the personnel of the FIPAG Head Office in Maputo. By June 2008 the TAT and Vitens Evides International had managed to train $28 \%$ of the staff of Inhambane and Maxixe, $32 \%$ of Xai-Xai, and $28 \%$ of Chókwe.

The main objective of the elaboration and implementation of improvement plans, programmes and SOPs was to describe what to do and how to do it. These plans and procedures were to contribute to the improvement of the professionalism and performance of the companies in the longer term. By the end of the contract 33 improvement plans/programmes were elaborated.
Material and equipment was required for improving the operation and maintenance (pumps, computers, stock, cars, etc.) and necessary to implement all of the various plans, programmes and SOPs. Some small investments, such as the installation of $120 \mathrm{~km}$ of network and the building of 8 new boreholes, were also made with money originating from Vitens Evides International and from the 'Water for Life' programme. The implementation and training of staff to use management information systems (MIS) was also part of this activity. Accounting and commercial software were also implemented.

A key task of Vitens Evides International's activities concerned the coordination with FIPAG Head Office staff regarding construction works, which were financed by the AfDB project. Vitens Evides International helped to identify the needs of the systems by creating a database that included water sources needs, distribution needs, etc. All of the systems that were going to be constructed were analysed to determine if they were adequate for the cities and to avoid any overlap with existing infrastructure.

As the partnership progressed the role of Vitens Evides International changed. At the beginning of the partnership Vitens Evides International assumed a more directive role, in which the focus was on providing operational support. Over time, as the capacity of the utilities increased, Vitens Evides International concentrated its activities more on supporting managerial skills and monitoring. Or, as one of the FIPAG officials explained: 'the companies are not being helped to create plans anymore; they are now being helped to improve the plans. They no longer need to know how to do things, but how to innovate; not how to start, but how to develop. So the objectives are still there but the way and the focus is what has changed' (Mabote, 2009).

\section{Performance improvements}

In the end, the test of success lies in the level of performance that the 4 utilities managed to achieve over the period of the TAC. As Table 3 shows, performance in the 4 utilities showed considerable improvements over the 2004-2008 period. Almost all indicators show improvements. Of particular importance for the MDGs on water supply is service coverage. These showed improvements, which, if continued at the current pace, would achieve the target of halving the population without access to adequate water supply.

Even though the various stakeholders agreed that the goals of the TAC had been achieved, they pointed out the fact that there is still much room for improvements and that this was the reason why FIPAG decided to create a second TAC with Vitens Evides International that will end in 2012.

\section{The tariff}

The aim of the WOP with VEI was to create autonomous water utilities. This also means financial autonomy (i.e. operating on the basis of cost-recovery). At the time of conducting this study, this had not been achieved. On the one hand, tariff increases designed to improve levels of cost-recovery were put on hold in 2008 and 2009, in the run up to elections. At the same time, raising the tariff to cost-recovering (including investment costs) is seen as unfeasible. The director of VEI, Jan Hoffer, indicated in 2008 that he considered the idea of full cost-recovery for water utilities in Mozambique to be a myth. Rather, the aim is to try to recover operation and maintenance costs, which, at the time of the fieldwork for this study, not all utilities had managed to do. 


\begin{tabular}{|c|c|c|c|c|c|c|c|c|c|}
\hline \multicolumn{10}{|c|}{$\begin{array}{c}\text { Table } 3 \\
\text { Selected performance indicators, } 2004-2008\end{array}$} \\
\hline \multirow[b]{2}{*}{$\begin{array}{l}\text { Key Performance } \\
\text { Indicator }\end{array}$} & \multirow[b]{2}{*}{ Unit } & \multicolumn{2}{|l|}{ Chokwe } & \multicolumn{2}{|c|}{ Inhambane } & \multicolumn{2}{|l|}{ Maxixe } & \multicolumn{2}{|l|}{ Xai Xai } \\
\hline & & $\begin{array}{l}\text { Dec. } \\
2004\end{array}$ & $\begin{array}{l}\text { June } \\
2008\end{array}$ & $\begin{array}{l}\text { Dec. } \\
2004\end{array}$ & $\begin{array}{l}\text { June } \\
2008\end{array}$ & $\begin{array}{l}\text { Dec. } \\
2004\end{array}$ & $\begin{array}{l}\text { June } \\
2008 \\
\end{array}$ & $\begin{array}{l}\text { Dec. } \\
2004\end{array}$ & $\begin{array}{l}\text { June } \\
2008\end{array}$ \\
\hline Coverage & $\%$ & $<50$ & 60 & $<50$ & 65 & $<15$ & 45 & $<30$ & 50 \\
\hline Population served & No. & 31.600 & 54.100 & 21.300 & 50.300 & 11.200 & 47.500 & 35.700 & 58.200 \\
\hline Water quality & & $\begin{array}{l}\text { Bact. } \\
\text { unsafe }\end{array}$ & Bact. safe & Bact. safe & $\begin{array}{l}\text { Bact.safe/ } \\
\text { treatment }\end{array}$ & $\begin{array}{l}\text { Bact. } \\
\text { unsafe }\end{array}$ & $\begin{array}{l}\text { Bact.safe/ } \\
\text { treatment }\end{array}$ & $\begin{array}{l}\text { Bact. } \\
\text { unsafe }\end{array}$ & Bact. safe \\
\hline Hours water supply & No. & $20-24$ & 24 & $20-24$ & 24 & $8-10$ & $20-24$ & $4-10$ & $16-24$ \\
\hline $\begin{array}{l}\text { Unaccounted for } \\
\text { Water }\end{array}$ & $\%$ & $>60$ & $<35$ & $>45$ & $<30$ & $>45$ & $<30$ & $>60$ & $<55$ \\
\hline Water metering & $\%$ & $<15$ & 80 & $<45$ & 75 & $<45$ & 90 & $<25$ & 80 \\
\hline $\begin{array}{l}\text { Billing/collections } \\
\text { Ratio }\end{array}$ & $\%$ & $<80$ & 90 & $<75$ & 95 & $<75$ & 85 & $<75$ & 95 \\
\hline $\begin{array}{l}\text { Operational cash } \\
\text { flow }\end{array}$ & $€$ & $<0$ & 30.000 & $<0$ & 12.000 & $<0$ & 45.000 & $<0$ & 30.000 \\
\hline
\end{tabular}

Source: Van Haren and Van den Horn (2008)

\section{Discussion: Salient features of the partnership}

In this section we would like to highlight a number of salient issues concerning the partnership. The salient issues concern the importance of investments, the questions of sustainability, the costs involved in financing partnership, the issue of replicability of such a partnership, the impact on autonomy, the role of trust, and finally some challenges encountered during the partnership.

\section{The importance of investment funds}

Based on the content of the interviews, the strength in the partnership lay in the combination of having access to investment funds (through the AfDB) and the capacity building activities undertaken by Vitens Evides International. Although the contribution of Vitens Evides International is acknowledged by the various actors involved in the partnership, it is the combination with the additional investment that resulted in the performance improvements witnessed. Without these investments, the performance improvements would have been much less spectacular. In the words of a FIPAG staff member 'Partnerships must always be accompanied by some kind of investment in order to be successful'.

\section{Questions of sustainability}

As the partnership progresses, it appears to become a victim of its own success. The capacity building activities have led to a group of relatively well-trained staff. This has also been recognised by FIPAG, which sees the staff of these 4 utilities as having more experience than other staff. As a result, FIPAG have reallocated staff from the 4 utilities to other water utilities under the control of FIPAG in Mozambique, with the aim of improving performance of these utilities. During the later stages of the partnership, in particular, many transfers of staff occurred, specifically involving people that had already been trained and who were performing well.

The consequence of this has been that the capacity of the 4 utilities has become somewhat weakened, or, as expressed by a representative of the Dutch Embassy: 'The true question is if they will be able to do it on their own? This is why I insist
Vitens Evides International should stay longer. The big catastrophic issue in development is sustainability; we still think of projects of 1 or 2 years. You still have to keep an eye and give the crucial support even in later stages; you still need to keep an eye even if very limited. But this issue is very difficult to talk about to development agencies; they want short projects with quick gains'.

\section{The costs involved}

Although the performance improvements of the 4 utilities are clear, one can raise a question regarding the costs involved in this particular partnership and particularly if similar benefits could not have been achieved at less costs. Regarding this question the opinions of the various actors involved in the partnership differ somewhat. Quite a few respondents believed that it could be possible to follow a similar approach using local consulting firms, and that their knowledge would be up to the task. The question was, however, if this would actually lead to fewer costs. As a respondent from FIPAG explained: 'moneywise it is maybe better to have Vitens Evides International because in Mozambique you would have to hire a consultant company and they are very expensive' (De Sousa, 2009).

A staff member of Vitens Evides International argued that 'of course you could do it cheaper and I'm sure there are a lot of qualified people that could do the same that we do and we should not pretend we are better or worse than local people who could also do this. But we run a very good water company so we know what we are talking about' (Kamstra, 2009). Finally, some respondents pointed out that Vitens Evides International used Dutch staff with heavy reliance on the local (Mozambican) TAT. In their mind this helped decrease the costs without losing expertise.

\section{Questions of replicability}

Perhaps the most intriguing question about the partnership is the question of how replicable it is for other countries or with other partners. Based on the development of the partnership, it would seem that replicability (on a wide scale) is highly unlikely. First of all, Vitens Evides International invested considerable funds (more than $€ 2.3$ million) in this partnership at the start of the TAC and during the period of the partnership 
operated under a 'PPP' contract. These investments were later viewed as a strong basis for the eventual trust between FIPAG and VEI. The investments came from contributions from the mother companies Vitens and Evides, as well as from the 'Water for Life' fund to which customers of these utilities can donate money. The question is, of course, how many public utilities are able to undertake such investments from their own funds as part of a water operator partnership? Secondly, the partnership benefited from 2 external financiers. Vitens Evides International very pragmatically made use of the 'call for ideas' for PPPs by the Dutch Ministry for Development Corporation to develop a 'PPP' based on the existing TAC. At the same time, the loan for investment by the African Development Bank also played an important role in the performance improvements that the partnership was able to achieve. It is unlikely that similar (external) funding opportunities will frequently exist. Thirdly, Vitens Evides International, at an early stage, committed itself to a long-term partnership, essentially stating that it would remain involved for a large number of years. The question is if many organisations would be willing to make such a commitment at such an early stage. Fourthly, the size and situation of the utilities at the start of the partnership made for a highly suitable partnership. The utilities are relatively small (serving between 50000 and 60000 people), which meant that an outside party like Vitens Evides International could have a considerable impact on the utility. A similar partnership with a utility operating at a much larger scale would likely have less impact (or the partnership would have to address specific issues, such as 'unaccounted-for-water' rather than target overall performance of the utility). Moreover, the utilities were at a very poor level of performance. The first steps in turning around performance are usually the easiest. As a result, the partnership could make large improvements in the functioning of the utilities relatively quickly.

\section{The impact on autonomy}

The PPP proposal developed by Vitens Evides International and the Dutch Ministry of Development Cooperation highlights the objective for establishing autonomous water utilities. Based on the field interviews, however, the impact of the partnership on the level of autonomy is not clear-cut. This is partly due to the fact that the concept of autonomy has different dimensions. The level of autonomy depends both on the level of decision-making competencies of the organisation (managerial autonomy and policy autonomy) and the exemption of constraints on the actual use of these competencies (structural autonomy, financial autonomy, legal autonomy and interventional autonomy) (Verhoest et al., 2004). In the 4 utilities it appears that the level of autonomy, in terms of the level of decision-making competencies, was not impacted strongly by the partnership. At the beginning of the partnership the utilities already had considerable decision-making competencies (both managerial and policy autonomy). What was lacking, however, was the capacity to actually implement decisions that the utility could make. If anything, the development of plans and standard operating procedures has limited the discretionary powers of management in the utility. Also, in terms of interventional autonomy, the utility has become less autonomous over the time of the partnership. The introduction of key performance indicators to measure performance and to hold the utilities accountable has limited the autonomy of the utilities. What has greatly improved is the level of financial autonomy as the utilities have become better able to finance their operations and maintenance from revenues generated by the utilities themselves. Other dimensions of autonomy, such as structural and legal autonomy, do not appear to have been influenced much by the partnership.

To some extent, the finding that the level of autonomy of the utilities has not been impacted much (or may even have declined) can be linked to the way in which autonomy is defined. It appears that for Vitens Evides International the concept of autonomy revolves strongly around the concept of organisational capacity (and the ability to actually use the decision-making competencies that the utility has). This was then also the dimension that most of their activities targeted.

\section{The issue of trust}

Another interesting aspect of the partnership was the role of trust between the different parties involved. Although all parties agree that trust is important, the degree of importance attributed to trust differs between the partners. In particular Vitens Evides International appeared to place a lot of emphasis on creating trust between the partners. They consider trust to be the most important factor in such a partnership. The perspective of Vitens Evides International is also reflected in the TAC that was developed with FIPAG. The TAC was developed to be relatively flexible, allowing Vitens Evides International to adapt is focus in the partnership depending on developments within the utilities. Such a flexible arrangement can only work if there is a degree of trust between the partners involved, as such flexibility could also lead one of the partners to shirk their responsibilities.

For the Mozambican partners, it is difficult to reach a general conclusion on the importance of trust. On the one hand, a few respondents (from within the utilities) indicated that the issue of trust was important, but less so than for Vitens Evides International. The flexibility of the TAC was useful, but at the same time a source of frustration, as some FIPAG staff felt that the responsibilities of the partners were not clearly stipulated. After all, in the end the staff of FIPAG in the 4 utilities and the Head Office were responsible for the performance of the utilities and not Vitens Evides International. At the same time, at the FIPAG Head Office the issue of trust was considered critical. In fact they found that instead of the contract being leading for the partnership, the partnership was governed by 'trust'.

The most crucial moment in which the issue of trust played an important role was at the start of the partnership. As mentioned, the Delegated Management Framework had been designed to allow for private sector involvement in the Mozambican water supply and sanitation sector. Not surprisingly, the initial offer of Vitens Evides International to engage in a partnership to assist the utilities was met with considerable suspicion. The suspicion was mainly anchored in the possibility that Vitens Evides International may have been out to act as private operator within the Delegated Management Framework. What lessened the fears of privatisation was the fact that the initial phase of the partnership was fully financed by Vitens Evides International. In addition, Vitens Evides International spent a lot of time and effort trying to convince everyone of their intentions.

\section{Challenges faced during the partnership}

Although the partnership has lead to substantial performance improvements, the partnership also had its share of challenges. These challenges vary from cultural barriers to language barriers, and from the functioning of the Technical Assistance Team 
to different ideas about how the utility should be run.

The idea behind the Technical Assistance Team was that they would be present all of the time, knew the local culture and working environment and were also cheaper than flying in a staff member of Vitens or Evides. At the same time, the TAT had its problems. Because they were being paid directly by Vitens Evides International, the TAT was not seen as being part of FIPAG. Moreover, Vitens Evides International had opted for selecting relatively young professionals for the TAT as these professionals were likely to have a more open mind towards being trained and to developing a more commercial attitude towards running a water utility. For some employees of the utilities, this was difficult to accept. As one of the utility employees noted: 'they were called specialists, but they were just coming out of University. Some of them didn't even have a degree, but yet they were 'helping' people with more experience do their job' (De Sousa, 2009).

Other difficulties occurred with respect to the implementation of the standard operating procedures. These procedures created quite some resistance amongst the employees. As explained by a FIPAG employee: 'Some people were just used to working by heart and following their guts and not on following procedures' (De Sousa, 2009). Also, some employees in the utilities started feeling more confident about undertaking their tasks to the extent that they felt they could do without support from Vitens Evides International. For some this led to feelings of resistance towards the activities undertaken by Vitens Evides International.

Although the list of challenges could be expanded with additional examples, it is likely that many of such challenges are not specific to a water operator partnership, but rather apply to multi-cultural development projects in general.

\section{Conclusion}

Based on the key performance indicators and the interviews conducted during fieldwork, the water operator partnership between Vitens Evides International and FIPAG for 4 cities in southern Mozambique has been a success. Indeed, the pragmatic approach taken by Vitens Evides International in this partnership should receive the credit it deserves. The fact that the organisation committed itself early (and for a longer period of time) to the partnership, invested substantially in the partnership and made the most of (external) opportunities all contributed to this partnership. Moreover, despite a few challenges, the strategy adopted (with many short-term missions supported by the Technical Assistance Team and a Resident Manager) seemed to have been very successful.

At the same time, the success of the partnership in Mozambique does not necessarily mean that water operator partnerships are the main vehicle for achieving the MDGs on water supply in Mozambique. Three important issues, in this respect, can be highlighted. First, as mentioned in the introduction, the challenges for achieving the MDG targets are of a financial, institutional (including organisational capacity) and technological nature. The WOP only addressed part of these challenges (particularly those related to organisational capacity). If the other dimensions are not addressed, the impact of the WOP is unlikely to be very large. Secondly, a question regarding the sustainability of this particular partnership remains. Given the frequent transfers of staff from the 4 southern utilities to other utilities in Mozambique, the question arises as to what the impact will be on the performance of the southern utilities in the near future? Thirdly, the question arises as to how replicable this 'model' is? Based on the evidence that we gathered, we would be inclined to suggest that 'the model' may not be very replicable. Very few (public) utilities in this world will be willing and able to invest their own funds in such a partnership. Even fewer utilities would be willing to engage in a long-term commitment at a relatively early stage in the partnership. Moreover, it is not a frequent occurrence that external financing (to support the partnership and investments) is available to the extent that it was. Finally, Vitens Evides International largely happened upon its Mozambican partner by chance. It turned out to be an excellent partner. But it is likely that such 'chances' are few and far between.

\section{References}

AFDB (AFRICAN DEVELOPMENT BANK) (2002) Urban Water Supply and Sanitation - AfDB Loan Proposal, Appraisal Report African Development Bank.

BOURGUIGNON F, BENASSY-QUERE A, DERCON S, ESTACHE A, GUNNING JW, KANBUR R, KLASEN S, MAXWELL S, PLATTEAU J and SPADARO A (2008) Millenium Development Goals at midpoint: Where do we stand and where do we need to go? URL: http://ec.europa.eu/development/icenter/repository/mdg paper final 20080916 en.pdf (Accessed 16 August 2010).

BRAADBAART O (2007) Privatizing water: The Jakarta concession and the limits of contract. In: Boomgaard P (ed.) A World of Water: Rain, Rivers and Seas in Southeast Asian Histories. KITLV Press, Leiden.

BROWN A (2002) Confusing means and ends: framework of restructuring, not privatization matters most. Int. J. Regul. Gov. 1 (2) $115-128$.

BROWN C and HOLCOMBE A (2004) In pursuit of the Millennium Development Goals in water and sanitation. Water Polic. 6 263-266.

CRA (2009) The Delegated Management Framework. URL: http:// www.cra.org.mz. (Accessed November 20, 2009).

DE SOUSA L (2009) Personal communication with Luis De Sousa, 1 September 2009. Director of FRS (incorporating Chókwe, Inhambane, Maxixe and Xai-Xai), FIPAG, PO Box 91, Av. Filipe Samuel Magaia, No 1291 R/C, Maputo, Mozambique.

FOSTER V (1996) Policy Issues for the Water and Sanitation Sectors. IDB, Washington D.C.

FRANCEYS R (2008) GATS, 'privatization' and institutional development for urban water provision: future postponed? Prog. Dev. Stud. 8 (1) 45-58.

HALL D and LOBINA E (2000) Public sector alternatives to water supply and sewerage privatization: case studies. Int. J. Water Resour. Dev. 16 (1) 35-55.

HASHIMOTO R (2006) Hashimoto Action Plan - Compendium of Actions. United Nations Secretary-General's Advisory Board on Water and Sanitation.

IDELOVITCH E and RINGSKOG K (1995) Private Sector Participation in Water Supply and Sanitation in Latin America. World Bank, Washington D.C.

IWA, GWOPA and VEI (INTERNATIONAL WATER ASSOCIATION, GLOBAL WATER OPERATOR PARTNERSHIPS ALLIANCE SECRETARIAT AT UN-HABITAT, WITH VITENS-EVIDES INTERNATIONAL) (2009) Water Operators Partnerships - Building WOPs for Sustainable Development in Water and Sanitation. International Water Association, Global Water Operator Partnerships Alliance Secretariat at Un-Habitat, in collaboration with Vitens-Evides International.

JENSEN O (2005) Troubled partnerships: problems on coping strategies in Jakarta's water concessions. Paper presented at the $4^{\text {th }}$ Conference on Applied Infrastructure Research, 8 October 2005, Berlin. URL: http://www.infraday.tu-berlin.de/fileadmin/ documents/infraday/2005/papers/jensen Troubled Partnerships Problems.pdf (Accessed 19 August 2008).

KAMSTRA C (2009) Personal communication with Carl Kamstra, 18 August 2009. Financial Expert, Vitens Evides International, 
Reactorweg 47, 3542 AD Utrecht, The Netherlands.

KLIJN E and KOPPENJAN J (2000) Public management and policy networks: foundations of a network approach to governance. Public Manage. Rev. 2 (2) 135-158.

KOLK A, VAN TULDER R and KOSTWINDER E (2008) Business and partnerships for development. Eur. Manage. J. 26 262-273.

MABOTE A (2009) Personal communication with Angelo Mabote, 11 September 2009. Manager: Investments and Coordinator for Chókwe, Inhambane, Maxixe and Xai-Xai, FIPAG, PO Box 91, Av. Filipe Samuel Magaia, No 1291 R/C, Maputo, Mozambique.

MARA D and ALABASTER G (2008) A new paradigm for low-cost urban water supplies and sanitation in developing countries. Water Polic. 10 119-129.

MARA D, DRANGERT J, ANH NV, TONDERSKI A, GULYAS H and TONDERSKI K (2007) Selection of sustainable sanitation arrangements. Water Polic. 9 305-318.

MATSINHE NP, JUÍZO D, MACHEVE B and DOS SANTOS C (2008) Regulation of formal and informal water service providers in peri-urban areas of Maputo, Mozambique. Phys. Chem. Earth 33 841-849.

METHA M, FUGELSNES T and VIRJEE K (2005) Financing the Millennium Development Goals for water and sanitation: What will it take? Int. J. Water Resour. Dev. 21 (2) 239-252.

MWANZA D (2004) African public utilities not performing efficiently. Paper presented at the $12^{\text {th }}$ Union for African Water Suppliers Congress, 16 to19 February 2004, Accra, Ghana.

MWANZA D (2005) Promoting good governance through regulatory frameworks in African water utilities. Water Sci. Technol. 51 (8) 71-79.

NICKSON A (1997) The public-private mix in urban water supply. Int. Rev. Admin. Sci. 63 165-186.

OECD (ORGANISATION FOR ECONOMIC CO-OPERATION AND DEVELOPMENT) (2006) Evaluating the Effectiveness and Efficiency of Partnerships involving Governments from OECD Member Countries, ENV/EPOC(2006)15/FINAL. URL: http:// www.olis.oecd.org/olis/2006doc.nsf/LinkTo/NT000097BA/\$FILE/ JT03243465.PDF (Accessed 20 October 2008).

PANAYOTOU T (1997) The role of the private sector in sustainable infrastructure development. In: Gomez-Echeverri, L (ed.) Bridges to Sustainability: Business and Government Working Together for a Better Environment. Yale School of Forestry and Environmental Studies Bulletin Series 101. Yale University, New Haven.
PARKER D and KIRKPATRICK C (2005) Privatisation in developing countries: a review of the evidence and the policy lessons. J. Dev. Stud. 41 (4) 513-541.

PRASAD N (2006) Privatisation results: private sector participation in water services after 15 years. Dev. Polic. Rev. 24 (6) 669-692.

PROVAN K and BRINTON MILWARD H (2001) Do networks really work? A framework for evaluating public-sector organisational networks. Public Admin. Rev. 61 (4) 414-423.

RNE (ROYAL NETHERLANDS EMBASSY) (2004) Activity Appraisal Document for PPP Vitens-FIPAG. Royal Netherlands Embassy Maputo.

SPILLER P and SAVEDOFF W (eds.) (1999) Spilled Water: Institutional Commitment in the Provision of Water Services. InterAmerican Development Bank, Washington D.C.

SUEZ (2003) SUEZ Introduces its 2003-2004 Action Plan: Refocus, Reduce Debt, Increase Profitability. Press release, January 9 SUEZ, Paris.

TEISMAN G and KLIJN E (2003) Partnership arrangements: governmental rhetoric or governance scheme? Public Admin. Rev. 62 (2) 197-205.

UNICEF (2003) Mozambique: 55 children perish daily from unsafe water. URL: http://www.unicef.org/media/media_10219.html (Accessed 20 November 2009).

VAN DEN HORN P (2009) Personal communication with Peter Van Den Horn, 9 October 2009. Former Country Director in Mozambique, Vitens Evides International, Reactorweg 47, 3542 AD Utrecht, The Netherlands.

VAN HAREN A and VAN DEN HORN P (2008) Public-private partnership water supply in Choke, Inhambane, Maxixe and Xai-Xai (Mozambique): Activities report and financial statement Jan 2005 - Jun 2008. FIPAG/VEI.

WHO/UNICEF JOINT MONITORING PROGRAMME FOR WATER SUPPLY AND SANITATION (2008) Water for Life: Making it Happen. World Health Organisation and United Nations Children's Fund, Geneva and New York.

WOLTERS H and VAN DER HORN P (2008) Water Supply in Choke, Inhambane, Maxixe and Xai-Xai (Mozambique), Strategic Paper, VEI.

WORLD BANK (1997) Toolkits for Private Participation in Water and Sanitation. World Bank, Washington D.C.

WORLD BANK (1994) World Development Report 1994: Infrastructure for Development, World Bank, Washington D.C. 
http://dx.doi.org/10.4314/wsa.v37i4.17 Available on website http://www.wrc.org.za 